\title{
The Comparison of Basic Transportation Infrastructure and Freight Villages' Locations between Germany and
}

\section{Turkey}

\author{
Cenk Hamamcioğlu and Senay Oğuztimur \\ Ylldiz Technical University, Faculty of Architecture, Department of Urban and Regional Planning , Istanbul 34349, Turkey
}

\begin{abstract}
Transportation infrastructure and logistics facilities are partly different in both Turkey and Germany in terms of geographical location, industrial history and economy. The world witnesses the highest logistics performance index score in Germany. Meanwhile, Turkey experiences a promptly development. As Europe's largest economy and second most populous nation, Germany leads in developing logistics strategies and services as a key member of the EU's economic and political structure. On the other hand, Turkey possesses a strategic location between the continents but conventionally problems in transportation mode split and interconnectivity of systems that interfere with "hub" role for its region and achieve economic benefit. This paper aims to focus on transportation mode sprit and location decision of freight villages in Germany to understand the mind behind success. With this purpose, first section is substantially based on secondary data gathered from Turkish/German Statistical Institutes, Ministries of Transportation and NGO's of the sector and academic studies. Finally, the lessons to be taken for Turkey's future policies are presented. Results indicate that, the finest detail is hidden behind the railway investments and their connections with other modes for Turkey. Germany's logistics workforce and infrastructure is geographically spread all over the country, but in Turkey, unbalanced regional development force country to polarised developed regions in the western part.
\end{abstract}

Key words: Transportation, freight village, Germany, Turkey.

\section{Introduction}

Germany ranks the first in the World Bank's 2014 Logistics Performance Index report of 160 countries and Europe's logistics giant, with annual revenues of nearly EUR230 billion. The second and third are France and UK and even their total revenues are less than Germany's. As ranking among the top three in the world for the foreign trade, Germany performs to be the global leader in logistics innovation, technology and services. In ensuring the success, Germany's central position in the EU makes the country an ideal location for logistics hubs and distribution centers contribute a considerable role. Serving over 82 million Germans, 150 million consumers in its nine neighboring countries, and

Corresponding author: Cenk Hamamcioğlu, Dr, associate professor, research fields: transportation, urban design and tourism planning. E-mail: chamamcioglu@gmail.com. nearly 500 million EU residents, Germany possesses a direct link to western and eastern European markets.

Germany is a global leader in logistics higher education as well. Over 100 universities and universities of applied science foster advanced logistics knowledge and make Germany the world's leader in developing new and innovative technologies and bringing them to the market. To maintain the logistics performance, German government provides companies with generous support for employment and $R \& D$ in addition to industry-specific incentive programs. An extensive and comprehensive logistics infrastructure that integrates state-of-the-art transportation networks with advanced telematics, IT, and telecommunications systems are offered. Moreover; social, economic and political stability as comprehensive indicators provide a solid base for logistics sector in Germany. 
Consequently, some of the mentioned reasons state why Germany is a benchmark for all countries that desire to develop as a world country. The clustering behind the achievement story is clear. This successful case is chosen for comparison with Turkey to influence good sides of this operating example.

\section{Methodology}

In order to obtain information about the institutional and functional aspects of logistics system and freight villages; an explorative study is an appropriate method because of the limited number of existing freight villages in Germany and Turkey. In terms of methodology, this study is based on desk research. To compare the two countries, both literature survey and reports prepared by governmental institutions are researched. This study is organized in a qualitative research method to make the comparison. We intend to compare a well-organized model and a developing country model. Qualitative research method is preferred so as to hold a general understanding of the picture.

This paper is essentially based on secondary data gathered from a wide variety of sources mainly through internet. Data originate from TUIK (Turkish State Institute of Statistics), UBAK (Ministry of Transportation, Maritime Affairs and Communication), DLHM (General Directorate of State Airports Authority), DTO (Chamber of Shipping), BOTAŞ (Petroleum Pipeline Corporation) and TCDD (Turkish State Railways) regarding Turkey. Germany data are originated from Federal Ministry of Transport and Digital Infrastructure, EUROSTAT (Statistical Office of the European Union) and European Commission Directorate-General for Energy and Transport Figures. Besides, CIA (Central Intelligence Agency) and World Bank web pages made the research easier. These publications bring to light the discourses, perceptions and strategies of public and some other actors and provide insight into their institutional goals. Depending upon these, statistical data analyses are done such as frequency analysis, average and percentage distribution.

\section{General View of Germany: The Reflections of Success}

Germany is ranked No. 1 by the World Bank's Logistics Performance Index in 2014. Also, the country is Europe's largest logistics market with around 230 billion Euros in annual revenue and the leader in logistics innovation, technology and services (Fig. 1). Germany has a strong and stable economy, the world's third largest exporting and importing country. On this account, logistics industry is the third largest sector of Germany after the wholesale and retail trade and the automotive industry.

With over 80 million inhabitants, Germany accounts for $16 \%$ of EU's total population. It has more consumers and more consumer spending power than any other country in the EU, accounting for $20 \%$ of the EU's total GDP (gross domestic product). EU's eastward shift has given Germany's logistics sector a significant boost. Germany has some of the Europe's most advanced transportation networks, with both road and rail densities double the EU average. A large well-trained workforce, plus a stable political and economic environment are also important factors. Together, they indicate Germany the best possible base for logistics.

Over recent years, industrial production in Germany has (on average) risen much faster than the economy as a whole. Leaving that aside, the size of the German economy alone makes the country attractive for logistics companies. The high per-capita

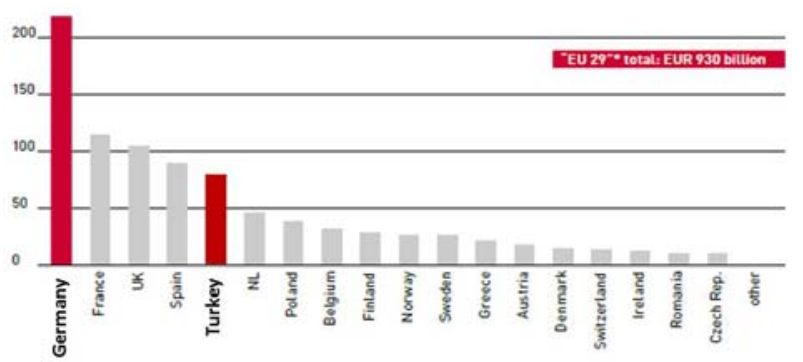

Fig. 1 Logistics Turnover in Europe [1]. 
incomes provide a positive factor for logistics firms as the local sale potential for companies depends on the size of disposable household incomes or private consumption. The German logistics sector also benefits from the integration into the global economy and has high ratios of exports and imports to GDP in G8. Also, Germany possesses as a logistics hub in its location at the heart of Europe with nine neighboring countries. This makes Germany the most important transit country and offers good opportunities for international freight handling.

Germany's polycentric economic structure compared to other countries also provides a magnet for domestic and foreign players in the transport business, as the result is an increase in transport routes. Since mid-1998, companies from the EU-15 have been allowed to conduct freight transport activities within other EU states (so-called freedom of cabotage).
Since 1999, the cabotage volumes in Germany have risen by around $60 \%$. Germany becomes the most important market for such cabotage traffic after its larger (in terms of land area) neighbor, France. Nearly $25 \%$ of all cabotage journeys within the EU are carried out in Germany [1]. Finally, the transport infrastructure in Germany is one of the country's key assets from a logistical point of view (Fig. 2). Germany scores well in an international comparison in terms of both the quality and scope of its transport infrastructure, even though in recent years, traffic volume has expanded faster than the corresponding infrastructure. The country has one of the most extensive motorway and rail networks in Europe. Its airports, seaports and inland ports are among the biggest and most up-to-date in Europe, and the Rhine is by far the most important inland waterway in the EU.
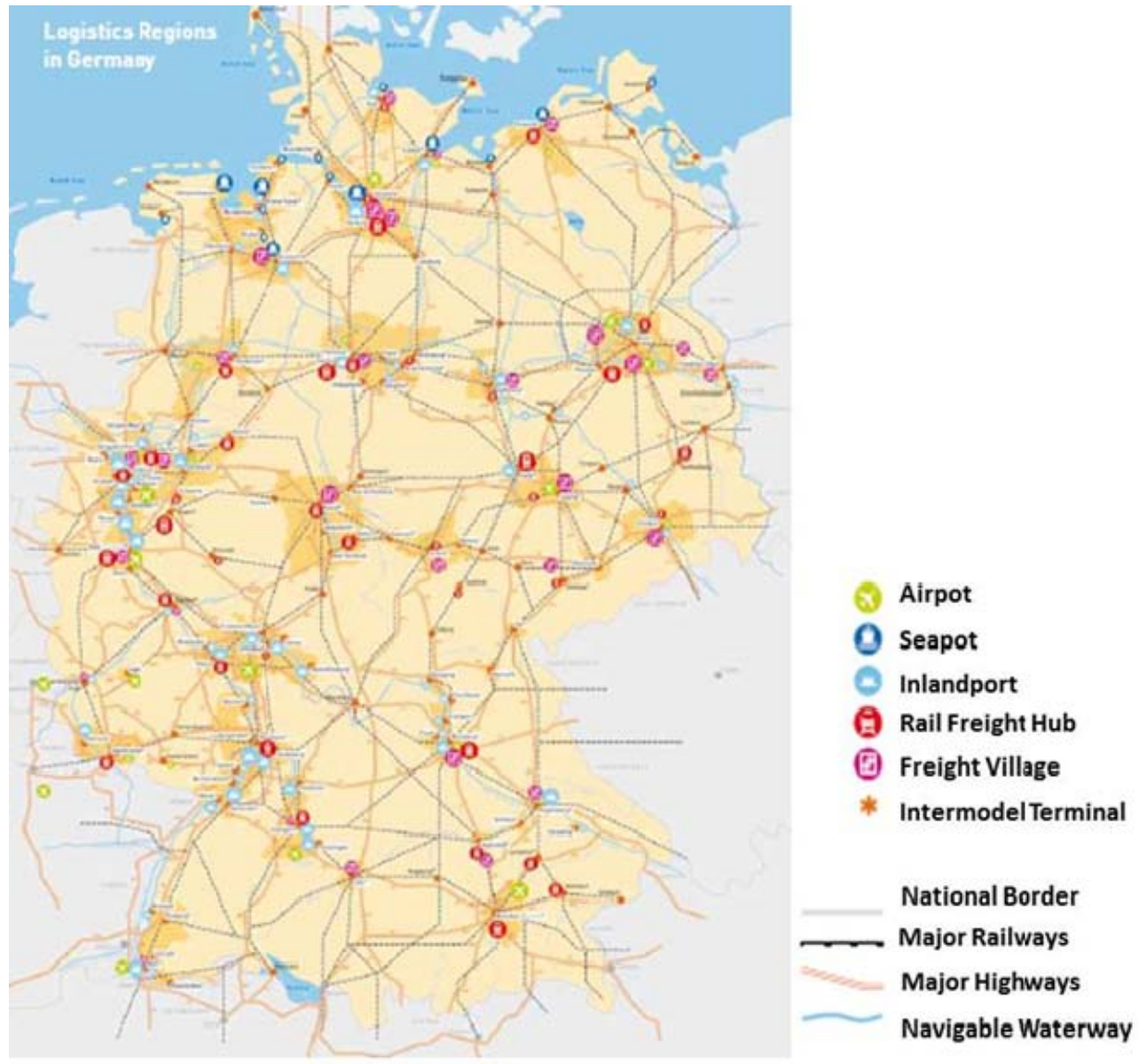

Fig. 2 Logistics regions in Germany [1]. 
Germany's turnover from logistics is almost more than half of the EU and far more than biggest competitors, France and UK, of the ten major logistics sub-market segments in the EU 29, German companies lead in seven. Germany's leading global logistic players include the Deutche Bahn Group, which ranks No. 1 in bulk logistics and also holds first place in Europe's general truckload segment.

The importance of Germany's central geographic location in an expanded European market is not only a significant benefit for logistic service providers, but is also a driving force of the nation's logistics market. As a result, Germany's logistics industry accounts for $8.8 \%$ of its GDP, which is significantly higher than the European average of $7.1 \%$ [1].

There are approximately 60,000 companies in Germany's logistics sector, employing almost 2.7 million individuals or roughly $7 \%$ of the total workforce [2]. The country's workforce is geographically concentrated along the Rhineland, through the industrial heartland of the Ruhr, to the North Sea and Baltic Ports. This matches the high volume of traffic to and from the Benelux countries and the UK in the west, and Scandinavia and the Baltic States in the north. Finally, EU's eastern expansion has given logistics in the eastern state of Brandenburg a significant economic boost. As a result, it is impossible to include all the components of Germany's expansive logistics landscape. Germany has a developed autobahn and integrated rails of freight villages and intermodal facilities, airports, seaports and inland ports.

\subsection{Modal Split of Freight Transport in Germany}

\subsubsection{Road and Railways}

Over the last 60 years or so, there has been a major shift in the breakdown of overall freight volume across the individual modes of transport in Germany: the road segment has steadily increased at the expense of rail and inland waterways. In 1950, the share for rail was $56 \%$ and for inland waterway, it was nearly
$24 \%$, whereas the road share came to only around $20 \%$. As per 2013, on behalf of Eurostat Statistics [3] data, the road share of the modal split is $70.7 \%$, whereas rail (nearly 19.1\%) and inland waterway (about $10.2 \%$ ) trail a long way behind. The main reasons for the gains made by road transport are the flexibility and speed of trucks compared to other modes of transport. Ongoing shift in the production structure of the economy from traditional bulk goods to high-quality products, the growing logistics demands of customers as well as the increase in small consignments (heavily associated with the rise of e-commerce) were also pivotal to the success of road transport. In addition, the road infrastructure was expanded extensively following World War II.

A turnaround in the modal split trend has, however, been looming for a few years. The sharp increase in the price of diesel and the truck toll contributed to goods traffic growing much more slowly than rail in recent years. In recent years, rail freight volumes in Germany grew at an average of $8 \%$ per year. This was largely due to private rail companies, which increased their traffic by an average of $40 \%$ per year. This success of private rail operators in Germany shows that competition in the rail sector can positively impact the entire transport sector. At the same time, rails play a hugely important role in the seaport hinterland transport segment, which is increasingly developing into a bottleneck at many major German ports.

\subsubsection{Air Freight and Sea Freight}

Given its small share of total domestic freight traffic in Germany, air freight appears quite insignificant at first glance. This is also due to the fact that air freight comes into its own primarily over long distances. Air freight is thus one of the fastest growing modes of transport, both in Germany and worldwide. Mainly high-value and usually time-sensitive items are transported by air.

By contrast, over $90 \%$ of international freight traffic in volume is transported by sea. Sea freight 
thus constitutes the backbone of globalization. The main reasons for the success of container shipping are the short loading and unloading times for ships and the favorable conditions for forwarding consignments using other modes of transport; container standardization makes this possible.

\subsubsection{Inland Shipping}

According to Eurostat 2013, Germany is the biggest inland shipping market in the EU with a share of $40 \%$ of freight traffic. Duisburg is home to Europe's largest port that caters exclusively for domestic shipping. In Germany, most inland ports are well connected with other modes of transport. In the seaport, hinterland transport segment as well as inland shipping performs a small but significant function as a feeder and forwarder of goods to their final destination. This has played a not inconsiderable part in the steady increase in container utilization in domestic shipping as well. Overall, inland shipping has nevertheless registered the lowest growth of all modes of transport in Germany in recent years. The main reasons for this are the above-mentioned goods structure and logistics effects along with other factors. Domestic shipping is particularly susceptible to external factors such as extremes of weather.

\subsection{Freight Villages in Germany}

Thanks to the perfect location, Germany is the continent's commercial hub at the core of European Union, bordering nine countries. That is why more goods pass through Germany than through any other countries in Europe. In the north, Germany's seaports are important conduit for trade with the UK, Scandinavia and the Baltic States. In addition, road and rail links through the Jutland Peninsula provide easy access to Denmark and the rest of Scandinavia. In the west, an extensive network of roads, rail links and inland waterways feeds into France and the Benelux countries of Belgium, the Netherlands and Luxemburg. Again in south, Germany has strong commercial ties with Switzerland and Austria and direct road, rail and water links with the Balkan states dominate the freight villages' locations as well.

In order to analyze the logistics system in Germany, freight villages are taken into consideration after the basic transportation system is analyzed. Basically, it is known that freight villages must fulfill various functions to comply with the major requirements of the underlying conceptual framework. Freight village operations to serve these functions are based on three basic logistical functions. First of all, the multimodal linkage of different transport modes and high-performance handling and storage systems within freight villages contribute to the efficient transport, handling and storage of products and goods within a logistics network [4-6]. Second, freight villages must fulfill a planning and dispatch function by ensuring the timely and capacity-related allocation of goods and/or tasks to available resources [7, 8]. In addition, the third basic function of freight villages pertains to the provision of logistical services on site in a way that ensures that logistical processes are handled without interference. Based on these basic functions, freight villages must also perform specific target functions to ensure that freight village operation enables powerful logistical processes such that products and goods are provided faster and at lower cost while improving freight traffic. Primarily, the consolidation of freight flows and the implementation of intelligent, multimodal transport chains create considerable potential to improve rationalization, leading to time- and cost-saving effects. As a result, freight villages also perform a streamlining function within the entire supply chain and logistical network. Moreover, well-positioned freight villages near urban areas also contribute to the establishment of intelligent logistical services to provide products and goods effectively [9]. For this reason, it is necessary to consolidate the flow of goods and to ensure effective local distribution of goods. The requirement of ensuring the effective distribution of goods calls for involvement of high-performing logistics providers in 
freight villages. These logistics providers are responsible for the supply and disposal of products and goods in a way that lowers delivery frequency due to improved capacity utilization. The polycentric structure of the economy means that no surprise that many logistics facilities with differing specialties have managed to develop.

The two seaports in Hamburg and Bremen (i.e., Bremerhaven) are Germany's "Gateways to the World" and with their links to other modes of transport, they are the most important logistics locations in the north of the country. But smaller ports of the North Sea and Baltic Sea are also becoming more important, since short-haul maritime traffic in the EU, for example, has been rising for a number of years. The Rhine-Ruhr, Rhine-Main and Rhine-Neckar regions are among the major logistics centers with a high degree of inter modality, due to their considerable economic vitality in no small measure. Nearly $90 \%$ of air freight traffic in Germany is processed via the airports in Frankfurt, Cologne/Bonn, Leipzig/Halle and Munich. Berlin conurbation possesses the potential to expand its role as a regional hub for traffic heading towards Eastern Europe. The partially decentralized intermodal freight villages in Germany are becoming more important for the efficient dovetailing of different modes of transport, and they help to achieve the optimum use of load capacities. Locating their facilities near to such freight villages is appealing for logistics firms and industrial segments that involve high levels of freight transportation.

In Germany managed by the state system, a small or a large freight village is located in each state given in Appendix 1. Taken from the top level, three main freight villages (Berlin, Bremen and Regensburg) are observed at the top of the hierarchy in nationwide (Fig. 3). These regions rank also the highest per capita income of people in Germany. So this wealth reveals perfect infrastructure of all logistics facilities. The secondary high stage logistics villages with high accessibility, wide hinterland and a large volume of business have located in all the border provinces of the country. That is because Germany is a foreign trade-oriented country. On the other hand, the three states where Kassel, Magdeburg and Erfurt of small stage level of logistics villages are located, preserved by UNESCO in terms of historic and cultural tourism potentials involving vital fertile agricultural lands of

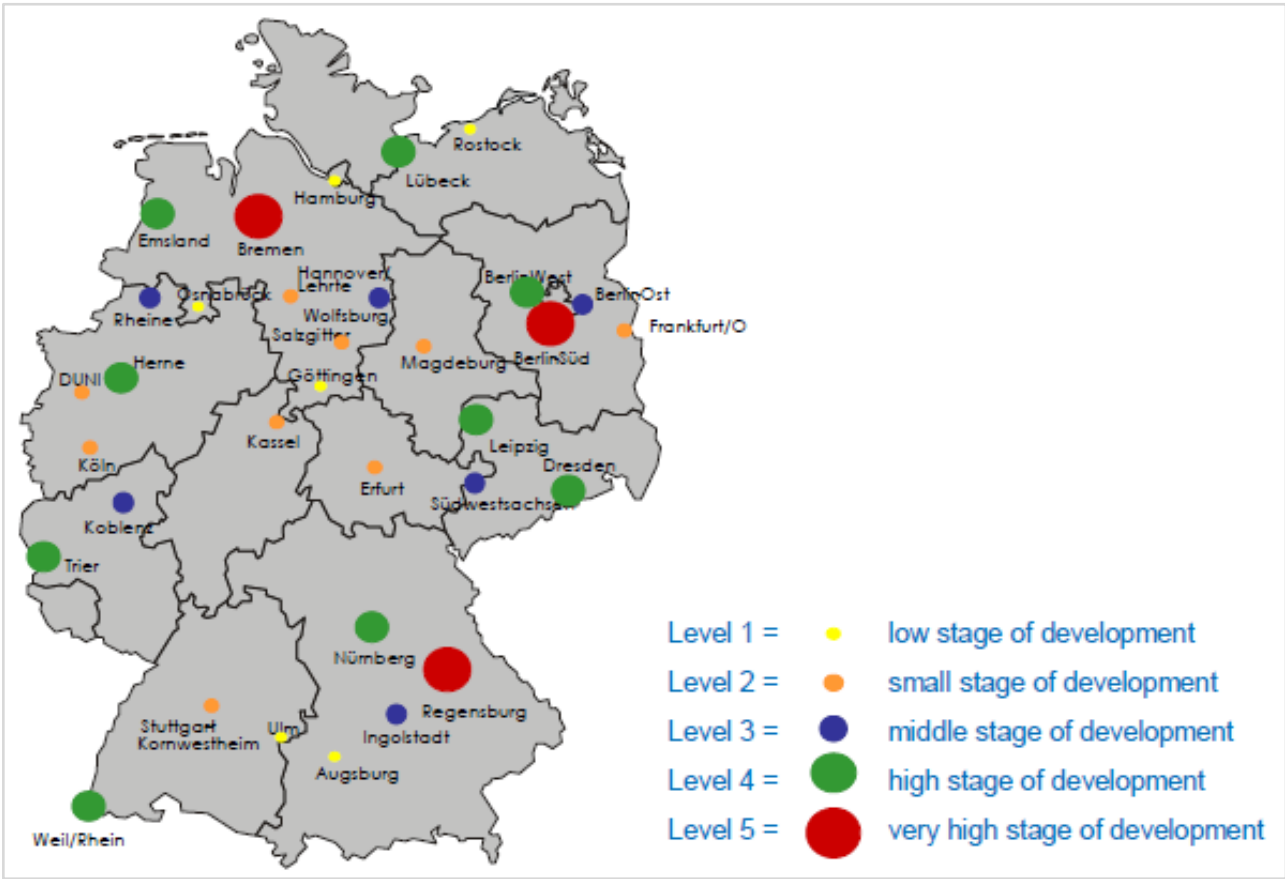

Fig. 3 The stages of freight villages in Germany [10]. 
Germany as well. These locations are subsequent service sector hubs. However, absence of a prior freight village in these three mid-states of Germany does not mean that they cannot take advantage of opportunities in the immediate vicinity. Moreover, these villages are supported by a developed intermodal transportation. There are different roles of each of logistics centers in the country. For example in particular, Berlin is positioned as a major hub for cargo from/to Eastern Europe and its position in the hierarchy is also enhanced by strong connections and access from other freight villages. This map (Fig. 3) has parallels with the industry distribution of Germany by reason of the locations. The more industrialized, the better logistics facilities remain. One more important point is that Germany has close economic corporations with the wealthy neighboring countries especially in north-east and south-east. So that the freight villages in Levels 4 and 5 are located by considering these points.

\section{Brief Summary of Logistics, Freight Villages and Transport Problems in Turkey}

Turkey locates at the heart of Europe (south east), Asia (Middle East and central) and Africa (north east) bordering eight countries. In terms of freight transport, intercontinental position makes Turkey a major transit country and also provides potentials to be a hub as well. At the same time, Turkey is a rapid developing country with more than 80 million inhabitants as per 2014 and a great deal of prospective young population and dynamic market conditions, however, has some critical challenges behind the regional policies followed in logistics sector to convert this geographical advantage and work force into economic profit.

Particularly, the main land of Turkey (Anatolia) possesses some difficulties because of mountainous and bumpy terrain but, has a competitive advantage in maritime transport since it is surrounded by seas on three sides $(8,333 \mathrm{~km}$.) with the Mediterranean, the Aegean, and the Black Sea, together with the straits of the Dardanelles and the Bosphorus. This is one of the reasons for maritime to be the most preferred mode with a share of $85 \%$ in terms of volume.

In between 2004-2013, the total amount of carried cargo increased from 174.846 million ton-km to 253.268 million ton-km with a growth rate of $45 \%$. The general overview of transport sector in countrywide clearly demonstrates road transport as the major mode for national freight transportation where $88 \%$ of goods are carried (Table 1). Meanwhile, Turkey is on the network of eight international roads, however, unstable regional political atmosphere, for example, since 1990s in Iraq and 2011 in Syria, adversely affects international freight transport via road transport although infrastructure of roads and highways are comparatively developing quickly. On the other hand, statistical data in between 2004-2013 indicates that maritime share in freight transport advanced from $4.2 \%$ to $6.8 \%$ in ten years. And the infrastructure of railways are started to be repaired and developed. However, the efforts could not avoid decline in the rail sectorial share of freight transport from $5.4 \%$ in 2004 to $4.4 \%$ in 2013 [11].

Recently, logistics sector in Turkey has made progress and experienced a $20 \%$ growth rate during the last five years and is forecast to increase to US\$ 120

Table 1 Modal split of freight transport in Turkey in 2013.

\begin{tabular}{lll}
\hline Transport Modes & & Volume \\
\cline { 2 - 3 } (instead of pipelines) & Ton-km (million) & $(\%)$ \\
\hline Road & 224.048 & 88.5 \\
Maritime & 17.312 & 6.8 \\
Rail & 11.177 & 4.4 \\
Airline & 0.731 & 0.3 \\
Total & 253.268 & 100 \\
\hline
\end{tabular}


billion by 2015 . In the year of 2013 , market size of logistics industry has been US\$ 98 billion while share in GDP was $12.3 \%$. As a result of domestic/international demand and domestic/ international passenger evolution, CAGR (compound annual growth rate) of the industry was $5.7 \%$ during 2004-2013. Industrial growth performance for 10 years was above GDP growth performance. The sector tends to grow faster than GDP in up cycles, and contracts more rapidly than GDP during recessions. The sector is highly sensitive to changes in international trade since a significant part of domestic movements are actually targeted toward international trade.

\subsection{Modal Split of Freight Transport in Turkey}

\subsubsection{Road and Railways}

In Turkey, road transport has experienced a significant process since 1950s. While 957 ton-km of freight was carried on the roads in 1950, it has increased to 224.048 ton- $\mathrm{km}$ in 2013 . One third of the road network that is $21.393 \mathrm{~km}$ developed into divided roads and the highways started to be established since $1980 \mathrm{~s}$ constitute $3.2 \%(2.127 \mathrm{~km})$ of the total length of road network in Turkey. In parallel with the development of road network, the total number of trucks operating reached $54 \%$ from 16,861 in 2000 to 25,930 in 2013 . The road freight (ton-km) expanded with a percentage of 47\% from 2004 until 2013 [12].

The railway network is available between certain cities (Fig. 4). 4,136 km of Turkish railway network was inherited from the Ottoman Empire. As of 2013 total length of the rail network reached to $12,097 \mathrm{~km}$ that is consisted of $8,846 \mathrm{~km}$ main lines $2,363 \mathrm{~km}$ branch lines and $888 \mathrm{~km}$ rapid rail lines. However, the integration of rails with ports is generally weak. For example, even the largest container port at Ambarl1-Istanbul does not have a rail connection. Izmir and Mersin already have railway connections, but the ratio to link hinterland by rail is around $2 \%-3 \%$

\subsubsection{Air Freight and Maritime Transportation}

Recently, Turkey experienced a tremendous development in the civil aviation sector and has grown ten times faster than the world average. Although the total cargo carried doubled to 731,962 thousand tons in 2013 but cannot contribute a remarkable share $(0.3 \%)$. As of 2015,35 airports are opened to international freight. Istanbul Atatürk is the largest cargo terminal with a volume of 586,319 ton covers $86 \%$ of all airports in Turkey. Istanbul Sabiha Gökçen has a share of 29,340 ton.

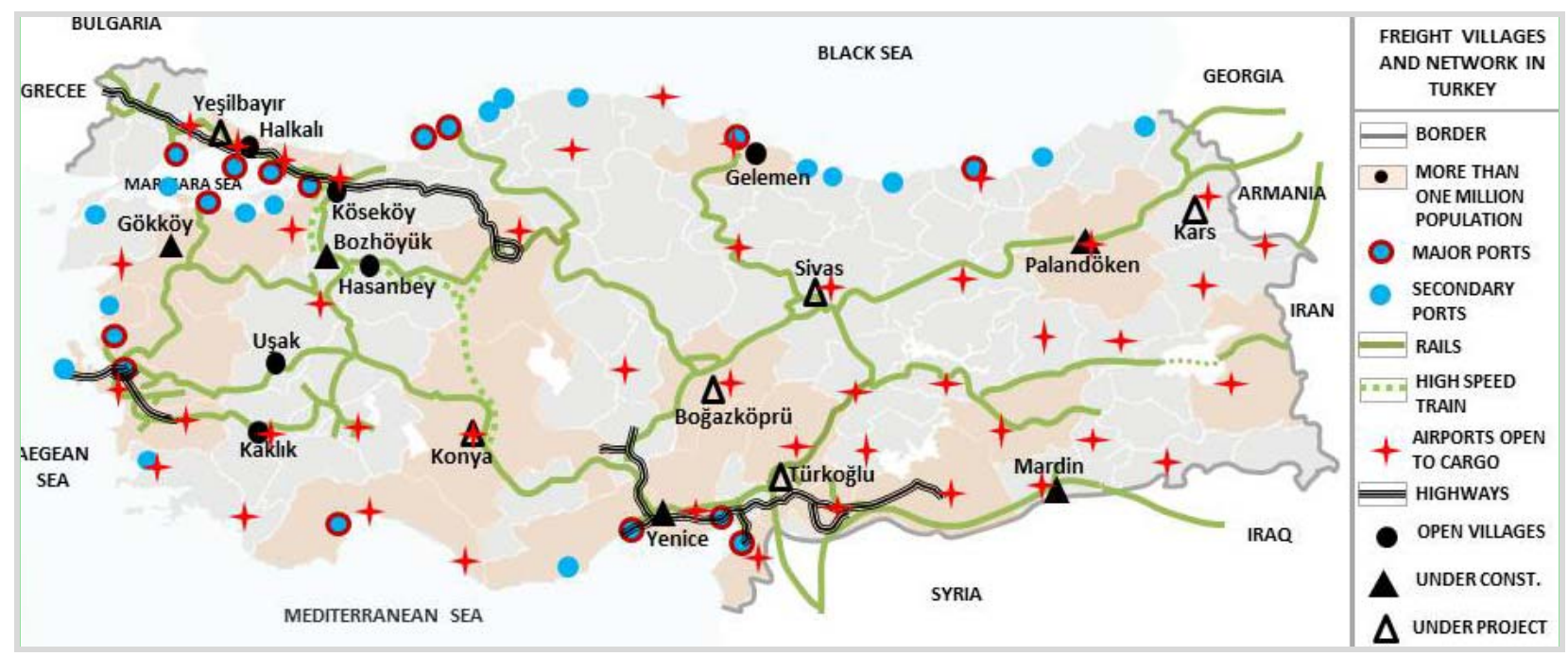

Fig. 4 Freight villages and transport network in Turkey. 
Cargoes arriving from Europe and America are handled in transit to CIS Republics; Iran, Iraq, and the Balkans and vice versa. Turkey's approach to maritime transport is consistent with the broad European principles and most liberally developing sector with a largely free market oriented economy. It covers nearly $7 \%$ of freight transport. Both in Turkey's exports and imports, with respective shares of $46 \%$ and $59 \%$, in total $85 \%$ of the volume of Turkey's foreign trade transportation is being carried by maritime transport. The amount of container handled has reached 7.89 million TEU (twenty-foot equivalent unit) in 2013 with an increase of $245 \%$ in ten years. Ambarlı (Istanbul), Izmir and Mersin ports are the biggest ports of Turkey in terms of annual handling and traffic capacity. Moreover, Aliaga, Samsun and Ceyhan regions meet the traffic of oil and its derivatives. Carrying freight via RoRo lines is a developing sector since last decades. The number of trucks/cars carried via RoRo lines was 220,345 in 2003 and increased with a percentage of 98 to 436,478 in 2013. As of 2013, there are 13 RoRo ports and 29 RoRo lines actively operating across the Mediterranean and Black Sea countries' ports [13].

\subsection{Freight Villages in Turkey}

Turkish logistics market has been recently exploring the concept of "freight villages". The government and private initiatives to establish logistics villages can be seen as a positive response to identify its constraint in the global market and strengthen its position. By 2015 in Turkey, there are 6 operating, 5 under construction and 6 projected logistics villages given in the Appendix 2 (Fig. 4).

However, as seen in Fig. 4, most of the logistics villages are located unbalanced in the northwest part of Turkey lack of a national logistics plan to comprise centralized management system and integrated viewpoint. In addition to this, when the hegemony of road transport in modal split of Turkish freight transport is remembered, the gab becomes significant.
Railway connected warehouses and highly performing railway network is the most important issue that Turkey needs to take into consider. Current logistics villages are mostly connected in an approximate distance to railway network, however a huge shift to trains is only possible if loads are kept in railway connected warehouses (Fig. 4). What is more, lines have problems with sufficient parking, loading-unloading, handling services with special equipment and separate areas as well as necessary qualified staff.

\section{The Comparison of Countries and Result}

Germany is a pioneer country performing successful logistics applications in the world while Turkey is a developing country. Due to its geographical location, Turkey offers potentials but, there are problems in assessing yet. After analyzing overall picture of both countries, this section will reveal similarities and differences and a roadmap for Turkey.

It should be noted that there are some important global challenges which are needed to be considered by all countries. One of them is energy. Energy prices have risen sharply over the last few years and affected all countries. Essentially, all modes of transport are affected by these cost increases in all countries. The transport sector has limited scope for making short-term adjustments to higher fuel prices. The long service of trucks, rolling stock, aircraft and ships militate against achieving rapid improvements in efficiency. The demand for energy is likely to rise faster than supply for the foreseeable future. Therefore, higher energy prices make transport costs a more important factor in the choice of business location.

Another global challenge is the carbon emissions and its negative results. Over the next few years, more measures motivated by environmental and climate policy concerns will impact the logistics and transport sectors. $\mathrm{CO}_{2}$ emissions in the $\mathrm{EU}$ transport sector rose by nearly one third that is faster than other sectors. 
The transport sector is now responsible for over $27 \%$ of all $\mathrm{CO}_{2}$ emissions in the EU. Therefore, the sector becomes the focus of greater environmental policy scrutiny.

Alongside to all these compelling global factors; when two countries are compared, as it is expected, some of the issues differ and some are similar. One of the similar points is that both countries would like to shift modal split from roadway to railway system. Shifting goods traffic from road to rail is an objective that Turkish and German authorities have advocated for decades. Behind these similarities, actually, there is a great gap between the countries' rail and road infrastructure network (see Table 2). Germany already has great infrastructure and transported freight volume while Turkey is so weak. Besides creating the corresponding infrastructure, it requires that the rail network in particular be opened up to more competition. It is already in public authority in Turkey but has arguments to be privatized. Since rail's specific advantages accrue primarily over long distances competition has to be boosted further throughout Europe. Efforts also need to be made to harmonize the differing rail systems within the EU. At the same time, politicians should not lose sight of the fact that the majority of the additional freight will still have to be transported by road in future.

Basic difference is the choice of transportation mode on behalf of railways. Due to rail's greater capacity and economies of scale, primarily higher transport volumes are transported over long distances by rail at lower costs. $38 \%$ of the responding freight villages in Germany reported performing transshipment of goods from road to rail. This leads to lower unit costs of transport and is environmentally friendly. Besides, transferring goods from road to rail allows for consolidation of consignments to achieve cost savings due to rationalization of transport and economies of scale. Although, there are 17 freight villages, which are connected to the railway network, currently freight transportation via rails is not operated efficiently. Just $2 \%-5 \%$ of total freight is transported by rail. Winkler and Seebacher [14] confirm that only $13 \%$ of goods are transshipped by trucks, while in Turkey, $88 \%$ of whole cargoes are carried by trucks.

Even if they have similar tendencies on the role of reducing the road and increasing the rail; in fact, there is a serious difference between the two countries. This difference does only not apply to both of these modes, but also to other aspects. One of the basic differences between two countries logistics policy occurs from the location decision of logistics villages. Hierarchy between the logistics villages in Germany is reflected in a significant way to the policies. Depending on the division of labor and hierarchy in sectorial distribution, accessibility becomes a substantial issue. However, in terms of Turkey, there is no such a hierarchy, there is no division of labor in the context of the sizes for the freight villages. Moreover, decisions may develop and the logistics villages' location decision proposals are changed by the role of political preference.

On the other hand, as it is well known, improving logistics performance is at the core of the economic growth and competitiveness agenda. Policymakers globally recognize the logistics sector as one of their key pillars for development. Indeed, inefficient logistics raises the costs of trading and reduces the potential for global integration. This is a hefty burden for developing countries trying to compete in the global marketplace [15].

Since 2007, the LPI (logistics performance index) has been informing the debate on the role of logistics for growth and the policies to support it in such areas as infrastructure, service provision, and cross-border trade facilitation. The results of Connecting to Compete 2014 Report of World Bank point to Germany as the best performing country with an LPI score of 4.12 and Turkey as over-income country with 3.50 (on a scale of 1 to 5). Strikingly high-income countries dominate the top 10 rankings. As expected, most of these countries are major and well-established 
The Comparison of Basic Transportation Infrastructure and

Table 2 Comparison of Germany and Turkey in terms of basic transportation infrastructure.

\begin{tabular}{|c|c|c|}
\hline & Germany & Turkey \\
\hline \multicolumn{3}{|l|}{ Basic } \\
\hline Population & $80,996,685$ & $81,619,392$ \\
\hline GDP_per capita & 27 th in the world, $\$ 44,700$ & 84th in the world, $\$ 19,600$ \\
\hline $\begin{array}{l}\text { GDP—composition, by } \\
\text { sector origin }\end{array}$ & Agriculture: $0.9 \%$, industry: $30.8 \%$, services: $68.4 \%$ & $\begin{array}{l}\text { Agriculture: } 8.2 \%, \text { industry: } 26.9 \% \\
\text { services: } 64.9 \%\end{array}$ \\
\hline \begin{tabular}{|l|} 
Labor force-by \\
occupation
\end{tabular} & Agriculture: $1.6 \%$, industry: $24.6 \%$, services: $73.8 \%$ & $\begin{array}{l}\text { Agriculture: } 25.5 \% \text {, industry: } 26.2 \% \\
\text { services: } 48.4 \%\end{array}$ \\
\hline Foreign Trade & $\begin{array}{l}\text { Export: } \$ 1.547 \text { trillion (2014 est.) } \\
\text { Motor vehicles, machinery, chemicals, computer and electronic } \\
\text { products, electrical equipment, pharmaceuticals, metals, transport } \\
\text { equipment, foodstuffs, textiles, rubber and plastic products } \\
\text { Imports: } \$ 1.319 \text { trillion (2014 est.) } \\
\text { Machinery, data processing equipment, vehicles, chemicals, oil } \\
\text { and gas, metals, electric equipment, pharmaceuticals, foodstuffs, } \\
\text { agricultural products }\end{array}$ & $\begin{array}{l}\text { Export: } \$ 176.6 \text { billion } \\
\text { Apparel, foodstuffs, textiles, metal } \\
\text { manufactures, transport equipment } \\
\text { Imports: } \$ 240.4 \text { billion } \\
\text { Machinery, chemicals, semi-finished } \\
\text { goods, fuels, transport equipment }\end{array}$ \\
\hline \multicolumn{3}{|c|}{ Transportation infrastructure } \\
\hline Total area & $357.022 \mathrm{~km}^{2}$ & $783,562 \mathrm{~km}^{2}$ \\
\hline Railways & \begin{tabular}{|l|} 
Total: $41,981 \mathrm{~km}(2008)$ \\
Standard gauge: $41,722 \mathrm{~km} 1.435-\mathrm{m}$ gauge $(20,053 \mathrm{~km}$ electrified $)$ \\
narrow gauge: $220 \mathrm{~km} 1.000-\mathrm{m}$ gauge $(75 \mathrm{~km}$ electrified $) ; 39 \mathrm{~km}$ \\
0.750 -m gauge $(24 \mathrm{~km}$ electrified $)$ \\
\end{tabular} & $\begin{array}{l}\text { Total: } 12,008 \mathrm{~km}(2012) \\
\text { Standard gauge: } 12,008 \mathrm{~km} 1.435-\mathrm{m} \\
\text { gauge }(3,216 \mathrm{~km} \text { electrified })\end{array}$ \\
\hline $\begin{array}{l}\text { Railways (m) per } \\
\text { capita }\end{array}$ & 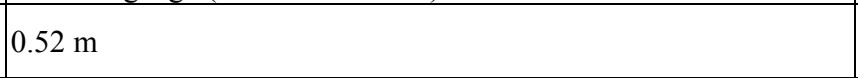 & $0.15 \mathrm{~m}$ \\
\hline $\begin{array}{l}\text { Railway density per } \\
\text { unit area }\end{array}$ & $0.117 \mathrm{~km}$ & $0.015 \mathrm{~km}$ \\
\hline Roadways & $\begin{array}{l}\text { Total: } 645,000 \mathrm{~km} \\
\text { Paved: } 645,000 \mathrm{~km} \text { (includes expressways) } \\
\text { Note: includes local roads }(2010)\end{array}$ & $\begin{array}{l}\text { Total: } 385,748 \mathrm{~km} \\
\text { Paved: } 352,268 \mathrm{~km} \text { (includes } \\
\text { expressways) } \\
\text { Unpaved: } 33,486 \mathrm{~km}(2012) \\
\end{array}$ \\
\hline $\begin{array}{l}\text { Roadways }(\mathrm{m}) \text { per } \\
\text { capita }\end{array}$ & $7.96 \mathrm{~m}$ & $4.72 \mathrm{~m}$ \\
\hline $\begin{array}{l}\text { Roadway density per } \\
\text { unit area }\end{array}$ & 1.8 & 0.49 \\
\hline Coast line & $2.389 \mathrm{~km}$ & $7.200 \mathrm{~km}$ \\
\hline Waterways & $\begin{array}{l}\text { 7,467 km (Rhine River carries most goods; Main-Danube Canal } \\
\text { links North Sea and Black Sea) }\end{array}$ & $\begin{array}{l}1,200 \mathrm{~km} \text { (not available for } \\
\text { transportation) }\end{array}$ \\
\hline Pipelines & $\begin{array}{l}\text { Condensate } 37 \mathrm{~km} \text {; gas } 26,985 \mathrm{~km} \text {; oil 2,826 km; refined products } \\
4,479 \mathrm{~km} \text {; water } 8 \mathrm{~km}(2013)\end{array}$ & Gas 12,603 km; oil 3,038 km (2013) \\
\hline Ports and terminals & $\begin{array}{l}\text { Major seaport(s): Baltic Sea-Rostock; North Sea-Wilhelmshaven } \\
\text { river port(s): Bremen (Weser); Bremerhaven (Geeste); Duisburg, } \\
\text { Karlsruhe, Neuss-Dusseldorf (Rhine); Brunsbuttel, Hamburg } \\
\text { (Elbe); Lubeck (Wakenitz) } \\
\text { Oil/gas terminal(s): Brunsbuttel Canal terminals } \\
\text { container port(s): Bremen/Bremerhaven }(5,915,487), \text { Hamburg } \\
(9,014,165)\end{array}$ & $\begin{array}{l}\text { Major seaport(s): Aliağa, Ambarlı, } \\
\text { Diliskelesi, Ereğli, Izmir, Kocaeli } \\
\text { (Izmit), Mersin (Içel), Limanı, Yarımca } \\
\text { container port(s) (TEUs): Ambarlı } \\
\text { (2,121,549), Mersin (Içel) (1,126,866) } \\
\text { LNG terminal (import): Izmir Aliağa, } \\
\text { Marmara Ereğlisi }\end{array}$ \\
\hline Merchant marine & $\begin{array}{l}\text { Total: } 427 \\
\text { Foreign-owned: } 6 \text { (Finland, Netherlands, Switzerland) } \\
\text { registered in other countries: } 3,420(2010)\end{array}$ & $\begin{array}{l}\text { Total: } 629 \\
\text { Foreign-owned: } 1 \text { (Italy) } \\
\text { registered in other countries: } 645 \\
\end{array}$ \\
\hline Airports & $539(2013)$ & $98(2013)$ \\
\hline Heliports & $23(2013)$ & $20(2013)$ \\
\hline Freight villages & 35 & 17 \\
\hline
\end{tabular}

Source: Prepared with CIA figures (www.cia.gov, last accessed: 03.06.2015). 


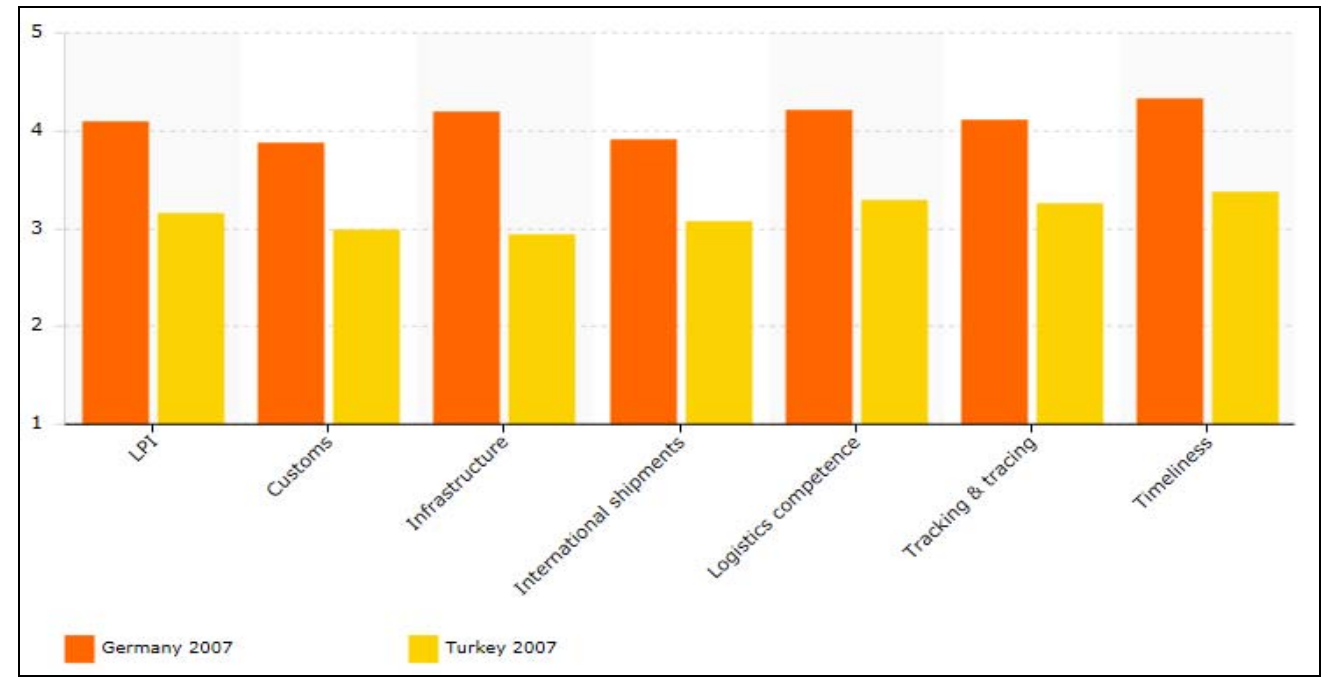

(a)

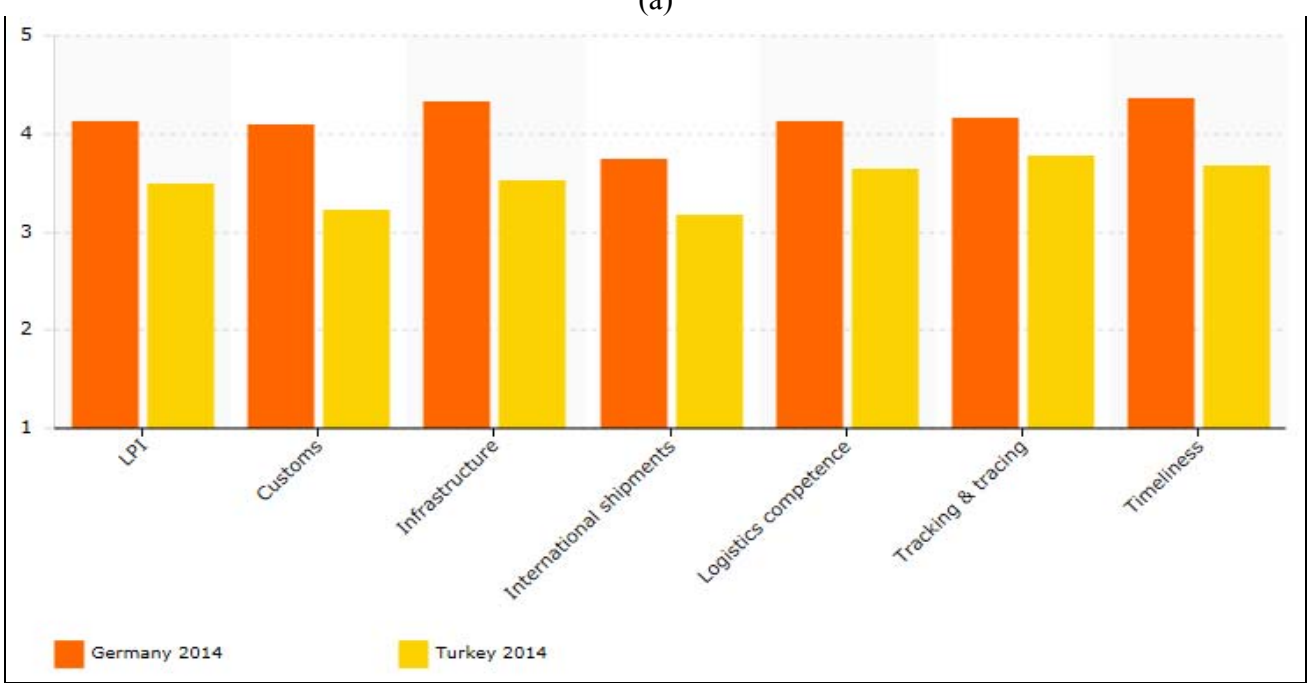

(b)

Fig. 5 Logistics performance of Germany and Turkey in: (a) 2007; and (b) 2014 [16].

logistics players with a dominant role in global or regional supply chains, foremost Germany does. As seen in the Fig. 5, Germany's performance is high in every criterion since 2007. Turkey's performance is better in many more technology-oriented criteria and worse in the ones related with physical infrastructure. In a detailed view, it is clear that the basic problem results from modal split of Turkey and inter modality deficiencies. Although by passing years Turkey is closer to compensate the difference, it still takes place in the upper middle class.

\section{Conclusion and Discussion}

Turkey's long-term economic policies are directed towards 2023 with a target of reaching an export volume of about US\$500 billion [17]. Besides the investments on the domestic infrastructure, a strategic shift is pursued in the transportation modal mix: from rail to road. In order to reach this aim, Turkey needs to support the country's ambitions in growing transport and logistics sector on the basis of unique and close geo-strategic positional markets.

The efficient mobility of people and freight is a prerequisite for modern economic success. Due to increasing globalization, transportation of freight and logistics plays an ever-important role in Turkey's ability to compete in the global market. Global supply chains require a large number of high-performing 
physical interfaces, such as container terminals, seaports and/or freight villages, to establish a perfect material flow along the entire world. From this point of view, Germany is one of the best-performed countries all over the world. Likewise, Turkey needs a kind of a "benchmarking" in order to overcome transportation and logistics infrastructural and strategic problems.

When Turkey and Germany's logistics performance is compared regarding transport indicators and the property of the logistics villages; Germany, has been observed as an important model not only for Turkey, but also for many countries. Reasoning behind Germany's logistics performance is to be the product of an extremely rational and strategic planning. Germany has been executed construction of basic infrastructure since the World War II years; at the same time, it is constantly renewing and trying to integrate to the environmentally friendly contemporary systems. All approaches and practices are planned for a more sustainable environment and economy. In Turkey, there are basic infrastructural deficiencies yet. One of the most key defects in Turkey is the absence of a logistics master plan which leads investments lack of aim and coordination.

In order for logistics to remain a catalyst for growth and employment in Turkey, authorized institutions should first and foremost create the necessary conditions in transport infrastructure. Turkey has real deficiencies in rail network as is seen in World Bank Performance Index. The imbalance of modal split should be one of the problems to overcome. To implement highly efficient transshipment points that contribute to high-performing supply chains, specific resources provided by freight villages are required to put intelligent multi-modal transport chains into practice.

Although Germany possesses a very extensive road and rail network, in the last few years, the volume of traffic in the road freight segment in particular has risen much faster than net investment in roads and bridges. According to the latest forecast from the Federal Transport Ministry, by 2025, Germany will see increases in goods traffic of some $70 \%$. The risk will thus increase if the development of road infrastructure continues to be a factor limiting the contribution of rail network in economic growth.

The policy areas for Germany are generally environment and cost efficiency oriented. For road transport, modernization and renewal have priority while refurbishing and upgrading rail network is taken into priority as well. The expansion of green and climate friendly rail services has to be accepted by the public. Efficient seaport connections are also essential for German economy, in particular connections by rail. There is much potential in inland navigation for relieving congestion on the roads and railways, but so far, it has remained untapped: (1) strengthen Germany as a logistics center; (2) enhance the efficiency of all modes of transport; (3) exploit the strengths of all modes of transport by interlinking transport infrastructure in an optimum manner; (4) promote the compatibility of transport growth with environmental protection and climate change mitigation; and (5) support the conditions of workers and training in the freight transport industry are basic topic titles that should be taken into account in a master plan.

\section{References}

[1] Germany Trade and Invest. 2010. Germany: Europe's Logistics Hub. Berlin: Germany Trade and Invest.

[2] Federal Ministry of Transport and Digital Infrastructure Policies for Mobility and Modernity. 2014. The Report of Federal Ministry of Transport and Digital Infrastructure Policies for Mobility and Modernity. October 2014, Hamburg.

[3] The European Commision. 2013. Eurostad Statistics of Transport Database.

[4] Tress, R. 1984. Das Güterverkehrszentrum als infrastrukturelle Schnittstelle des Güter-verkehrs. Düsseldorf: Verkehrs-Verlag J. Fischer. (in Germany)

[5] Kracke, R., Hildebrandt, J., Runge, W. R., and Voges, W. 1992. "Güterverkehrssysteme und -Zentren." In Raumordnerische Aspekte der großräumigen Verkehrs-infrastruktur in Deutschland, Schriftenreihe der Akademie für Raumforschung und Landesplanung, edited 
by Raumordnerische Aspekte der Großräumigen Verkehrsinfrastruktur. Hannover: Akademie für Raumforschung und Landesplanung (ARL), 38-61. (in Germany)

[6] Kracke, R., Hildebrandt, J., Runge, W. R., and Voges, W. 1998. "Güterverkehrs- und -verteilzentren." In Logistik: Gestaltung von Logistiksystemen, edited by Isermann, H. Landsberg/Lech: Verlag Moderne Industrie, 441-53. (in Germany)

[7] Krampe, H. 1993. "Territoriale Logistik: Lösungen für den Wirtschaftsverkehr." In Grundlagen der Logistik, edited by Krampe, H., and Lucke, H. J. München: Huss Verlag, 277-328. (in Germany)

[8] Fohrmann, M. 2000. Güterverkehrszentren als ein Ansatz zur Gestaltung und Bewältigung des Güterverkehrs vor dem Hintergrund einer konzeptionellen Erweiterung um virtuelle Aspekte. Frankfurt am Main: Peter Lang Verlag.

[9] Hesse, M. 2004. "Logistics and Freight Transport Policy in Urban Areas: A Case Study of Berlin-Brandenburg/Germany." European Planning Studies 12 (7): 1035-53.

[10] Wagener, N. 2008. Stages of Development: Freight Villages in Germany. Presentation in Kiev, April 8th, 2008.

[11] Turkish Ministry of Transport, Maritime and Communication (UDH-Türkiye Cumhuriyeti Ulaştırma,
Denizcilik ve Haberleşme Bakanlığı). 2013. 2003-2013 Ístatistiklerle Ulaştırma, Denizcilik ve Haberleşme. Ankara: Çağhan Ofser Matbaacılık. (in Turkish)

[12] Turkish Ministry of Highways (KGM-Karayolları Genel Müdürlüğü). 2014. Faaliyet Raporu 2013. Ankara: Strateji Geliştirme Dairesi Başkanlığı. (in Turkish)

[13] Industrial Development Bank of Turkey (TSKB-Türkiye Sınai Kalkınma Bankası A.Ş.). 2014. Lojistik Sektör Raporu. Accessed March 12, 2015. http://www.tskb.com.tr/i/content/733_1_Lojistik_Kasim_ 2014.pdf. (in Turkish)

[14] Winkler, H., and Seebacher, G. 2012. “An Empirical Investigation of German Freight Villages." Research in Logistics and Production 2: 399-410.

[15] World Bank. 2014. Connecting to Compete: Trade Logistics and Global Economy. Accessed May 5, 2015. http://lpi.worldbank.org/report.

[16] World Bank. 2014. Logistics Performance Index. Accessed June 5, 2015. http://lpi.worldbank.org/intern ational/scorecard.

[17] Soluk, M. H. 2011. "Turkey to Become a Regional Capital in Logistics." Turkish Logistics Catalogue 7 (4): 2.

[18] Gühnemann, A. 2013. An International Comparison of Transport Appraisal Practice, Annex 2 Germany Country Report. Project Report funded by Department of Transport, University of Leeds UK. 
The Comparison of Basic Transportation Infrastructure and

Freight Villages' Locations between Germany and Turkey

\section{Appendix 1}

\begin{tabular}{|c|c|c|c|c|c|c|}
\hline \multicolumn{7}{|c|}{ Freight villages in Germany } \\
\hline \multirow{2}{*}{ Logistics village } & \multirow{2}{*}{ Area in $\mathrm{m}^{2}(\times 1,000)$} & \multicolumn{5}{|c|}{ Modes of transport } \\
\hline & & Air & Road & Rail & Inland water & Sea \\
\hline Bremen & 4,960 & $\mathrm{X}$ & $\mathrm{X}$ & $\mathrm{X}$ & & $\mathrm{X}$ \\
\hline Hamburg & 100 & & $\mathrm{x}$ & $\mathrm{x}$ & & \\
\hline Kiel & 2,700 & & $\mathrm{x}$ & $\mathrm{x}$ & & $\mathrm{X}$ \\
\hline Lubeck & 623 & & $\mathrm{x}$ & $\mathrm{x}$ & & \\
\hline Rostock & 680 & & $\mathrm{x}$ & $\mathrm{x}$ & & $\mathrm{X}$ \\
\hline Osnagruck & 460 & & $\mathrm{x}$ & $\mathrm{x}$ & & \\
\hline Köln & 800 & & $\mathrm{x}$ & $\mathrm{x}$ & $\mathrm{X}$ & \\
\hline Heme-ernscher & 200 & & $\mathrm{x}$ & $\mathrm{x}$ & $\mathrm{x}$ & \\
\hline Hannover & 350 & & $\mathrm{x}$ & $\mathrm{x}$ & & \\
\hline Salzgitter & 1,100 & & $\mathrm{x}$ & $\mathrm{x}$ & & \\
\hline Wolfsburg & 34 & & $\mathrm{x}$ & $\mathrm{x}$ & $\mathrm{X}$ & \\
\hline Leipzig & 4,100 & & $\mathrm{x}$ & $\mathrm{x}$ & & \\
\hline Dresden & 390 & & $\mathrm{x}$ & $\mathrm{x}$ & $\mathrm{X}$ & \\
\hline Sudwestsachsen & 1,131 & & $\mathrm{X}$ & $\mathrm{x}$ & & \\
\hline Berlin-ost & 960 & & $\mathrm{X}$ & $\mathrm{x}$ & & \\
\hline Berlin-sud & 1,500 & & $\mathrm{x}$ & $\mathrm{x}$ & & \\
\hline Berlin-west & 1,272 & & $\mathrm{x}$ & $\mathrm{x}$ & $\mathrm{x}$ & \\
\hline Frankfurt & 1,070 & & $\mathrm{x}$ & $\mathrm{x}$ & & \\
\hline Augsburg & 710 & $\mathrm{X}$ & $\mathrm{X}$ & $\mathrm{x}$ & & \\
\hline Kassel & 600 & & $\mathrm{x}$ & $\mathrm{x}$ & & \\
\hline Erfurt & 2,800 & $\mathrm{X}$ & $\mathrm{x}$ & $\mathrm{x}$ & & \\
\hline Koblenz & 1,500 & & $\mathrm{x}$ & $\mathrm{x}$ & $\mathrm{X}$ & \\
\hline Trier & 450 & & $\mathrm{X}$ & $\mathrm{x}$ & $\mathrm{x}$ & \\
\hline Ulm & 550 & & $\mathrm{X}$ & $\mathrm{x}$ & & \\
\hline Stuttgart & 530 & & $\mathrm{X}$ & $\mathrm{X}$ & & \\
\hline Nurmberg & 2,550 & & $\mathrm{X}$ & $\mathrm{X}$ & $\mathrm{X}$ & \\
\hline Rheine & 1,400 & & $\mathrm{X}$ & $\mathrm{x}$ & $\mathrm{X}$ & \\
\hline Ingolstadt & 520 & & $\mathrm{X}$ & $\mathrm{X}$ & & \\
\hline Regensburg & 3,400 & & $\mathrm{X}$ & $\mathrm{x}$ & $\mathrm{X}$ & \\
\hline Emsland & 450 & & $\mathrm{x}$ & $\mathrm{x}$ & $\mathrm{x}$ & \\
\hline Gottingen & 70 & & $\mathrm{X}$ & $\mathrm{x}$ & & \\
\hline Jade Weser Port & 1,000 & & $\mathrm{x}$ & $\mathrm{x}$ & $\mathrm{X}$ & \\
\hline Magdeburg & 1,780 & & $\mathrm{x}$ & $\mathrm{x}$ & & \\
\hline
\end{tabular}


Appendix 2 [18]

\begin{tabular}{|c|c|c|c|c|c|c|}
\hline \multicolumn{7}{|l|}{ Freight villages in Turkey } \\
\hline \multirow{2}{*}{ Logistics village } & \multirow{2}{*}{ Area in $\mathrm{m}^{2}(\times 1,000)$} & \multicolumn{5}{|c|}{ Modes of transport } \\
\hline & & Air & Road & Railway & Sea & Situation \\
\hline Eskişehir-Hasanbey & 625 & $\mathrm{X}$ & & $\mathrm{X}$ & & Open \\
\hline Samsun-Gelemen & 330 & $\mathrm{X}$ & & $\mathrm{X}$ & $\mathrm{X}$ & Open \\
\hline Balikesir-Gökköy & 210 & & $\mathrm{X}$ & $X$ & & $\mathrm{UC}$ \\
\hline Kayseri-Boğazköprü & 1,511 & $\mathrm{X}$ & $\mathrm{X}$ & $\mathrm{X}$ & & UP \\
\hline Kahramanmaraş-Türkoğlu & 797 & $\mathrm{X}$ & $\mathrm{X}$ & $\mathrm{X}$ & & UP \\
\hline İzmit-Köseoğlu & 748 & $\mathrm{X}$ & $\mathrm{X}$ & $\mathrm{X}$ & & Open \\
\hline İstanbul-Halkalı & 220 & $\mathrm{X}$ & $\mathrm{X}$ & $\mathrm{X}$ & $\mathrm{X}$ & Open \\
\hline Erzurum-Palandöken & 327 & $\mathrm{X}$ & $\mathrm{X}$ & $\mathrm{X}$ & & $\mathrm{UC}$ \\
\hline Mersin-Yenice & 415 & & $\mathrm{X}$ & $X$ & $\mathrm{X}$ & $\mathrm{UC}$ \\
\hline Kars & 315 & $\mathrm{X}$ & $\mathrm{X}$ & $\mathrm{X}$ & & UP \\
\hline Bilecik-Bozhöyük & 400 & & $\mathrm{X}$ & $\mathrm{X}$ & & $\mathrm{UC}$ \\
\hline Sivas & 200 & $X$ & $\mathrm{X}$ & $\mathrm{X}$ & & UP \\
\hline Uşak & 140 & & $X$ & $X$ & & Open \\
\hline Denizli-Kaklik & 120 & $\mathrm{X}$ & $\mathrm{X}$ & $\mathrm{X}$ & & Open \\
\hline Konya & 1,000 & $\mathrm{X}$ & $\mathrm{X}$ & $\mathrm{X}$ & & UP \\
\hline Mardin & 400 & $\mathrm{X}$ & $\mathrm{X}$ & $\mathrm{X}$ & & $\mathrm{UC}$ \\
\hline Istanbul-Yeşilbayır & 1,000 & $X$ & $X$ & $X$ & & UP \\
\hline
\end{tabular}

Note: Total area: $8,758,000 \mathrm{~m}^{2}$.

UC: under construction; UP: under project. 